\title{
Peningkatan Efisiensi Sistem Pemanasan dengan Penambahan Grid pada Perforated Burner
}

\author{
Agung Sugeng Widodo \\ Teknik Mesin Universitas Brawijaya Indonesia, Jl. MT. Haryono, 167 - Malang 65145 \\ E-mail address: agung_sw@ub.ac.id
}

\begin{abstract}
Efficiency of a domestic gas stove depend on the kind of burner material and its configuration. In this study, a material in the form of a grid has been inserted into combustion chamber to modify flame characteristics. Grids made from stainless steel with different thickness were inserted between burner and loading. Ceramic stove cover was used to prevent heat release from flame. To develop the term of efficiency of the system, many parameters were measured as energy from fuel, cover temperature and water temperature. The results show that in certain fuel rate of $45 \mathrm{l} / \mathrm{h}$, a heating system with a grid of 5 $\mathrm{mm}$ has maximum efficiency of 58,8\% indicate a differentiation of $5 \%$ higher compared to the heating system with no grid. Grid material absorbs energy from combustion process, keep the temperature in the combustion chamber remain high also induce turbulence upstream the grid surface causing fuel-air mixing improved.
\end{abstract}

Keywords : efficiency, grid, perforated-burner, turbulence

\section{PENDAHULUAN}

Penggunaan kompor gas sebagai alat kebutuhan rumah tangga merupakan hal yang krusial untuk diperhatikan, terutama dalam masalah efisiensi dan polusi yang ditimbulkan. Dalam sudut pandang penggunaan secara massal, seperti dalam kasus konversi bahan bakar minyak ke gas yang dilakukan sebuah seperti Negara Indonesia, maka sekecil apapun perubahan efisiensinya akan berdampak kepada kondisi ekonomi sebuah negara. [1-3].

Beberapa penelitian mengenai kompor gas LPG yang berhubungan dengan pengaruh kecepatan gas, ketinggian beban masak (loading height), komposisi bahan bakar yang dipakai mempunyai pengaruh terhadap efisiensi sekaligus emisinya. Emisi pada kompor gas LPG mempunyai kadar CO lebih rendah dari pada kompor gas dengan bahan bakar minyak tanah ataupun biomassa, tetapi sebaliknya mempunyai kadar NOx lebih tinggi [4-7].

Penelitian tentang kompor LPG tetapi dengan mengubah burner konvensional menjadi burner radiant atau berporos seperti porous ceramic doped with earth element (PCR) atau porous radiant burner (PRB) juga dapat meningkatkan efisiensi dan menurunkan emisi gas buang secara signifikan [1,811].

Penelitian mengenai pengaruh loading height terhadap efisiensi sebuah kompor gas telah dilakukan oleh Widodo [12]. Hasilnya menunjuk-kan bahwa loading height pada sebuah operasional kompor gas akan mempunyai efisiensi maksimum pada loading height tertentu. Efisiensi maksimum sebesar $46.6 \%$ terjadi pada loading height sebesar $4 \mathrm{~mm}$ diperoleh pada kondisi laju alian massa 0.75 liter/menit pada penelitian di atas. Artinya jika loading height melebih atau kurang dari kondisi di atas, efisiensi sebuah kompor gas justru akan menurun.

Penambahan peralatan seperti selubung atau reflektor pada kompor gas dapat meningkatkan efisiensi sebesar $2-5 \%$ dibandingkan dengan tanpa selubung atau reflector [13-16]. Pada penelitian oleh Gohill, 2011, efisiensi sebuah dosmestik gas stove dapat mencapai $66 \%$ dengan penambahan selubung. Begitu pula penelitian oleh Widodo [14] terjadi penambahan sebesar $2,7 \%$ dari sebelumnya $43,9 \%$ tanpa menggunakan selubung.

Perubahan material sebuah kompor gas juga berpengaruh terhadap efisiensi kompor gas. Penelitian oleh Khan (2013), menunjukan bahwa perubahan material burner serta desain burner head juga berpengaruh terhadap efisiensi kompor gas. Peningkatan efisiensi sebesar $10 \%$ pada perubahan material burner dari cast iron head burner menjadi brass hear burner. Terjadi pula peningkatan efisiensi sebesar $10 \%$ apabila bentuk head burner diubah dari flat burner [17].

Pembakaran pada sebuah kompor gas LPG, adalah sebuah proses pembakaran pada kondisi fasa gas dan stabilisasi api tergantung pada permukaan burner dan konfigurasinya. Proses pembakaran pada kondisi tersebut dinamakan sebuah proses pembakaran nyala api bebas (free-flame-combustion) dengan ciri khas terdapat zona reaksi yang tipis dan gradien temperatur yang besar. Kondisi tersebut diatas merupakan hal yang bertanggung jawab terhadap inefisiensi dan pembentukan polusi pada kompor gas.

Penambahan material pada sebuah kompor gas diantara burner dan loading akan ber-pengaruh terhadap proses pembakaran yang terjadi. Dengan penambahan material berupa grid, maka akan terjadi perubahan konfigurasi bentuk flame, kestabilan api, serta gradien temperatur. Oleh karena itu pada penelitian ini akan dilakukan investigasi mengenai pengaruh penambahan material (material inserting) diantara burner dan loading terhadap efisiensi sebuah kompor gas LPG dengan jenis pembakar perforated burner. 


\section{METODOLOGI PENELITIAN}

Skematik instalasi penelitian dapat dilihat pada Gambar 1. Kompor gas yang digunakan pada penelitian ini adalah sebuah kompor gas LPG komersial satu tungku dengan merk QGC-101R. Sebagai loading, dipergunakan sebuah panci standar dilengkapi dgn tutupnya. LPG yang digunakan adalah LPG produksi Pertamina dengan tabung ukuran $3 \mathrm{~kg}$. Massa alir bahan bakar diukur dengan menggunakan sebuah flow meter merk Omega FL-1501A dengan range pengukuran $0.317-3.17$ SCFM.

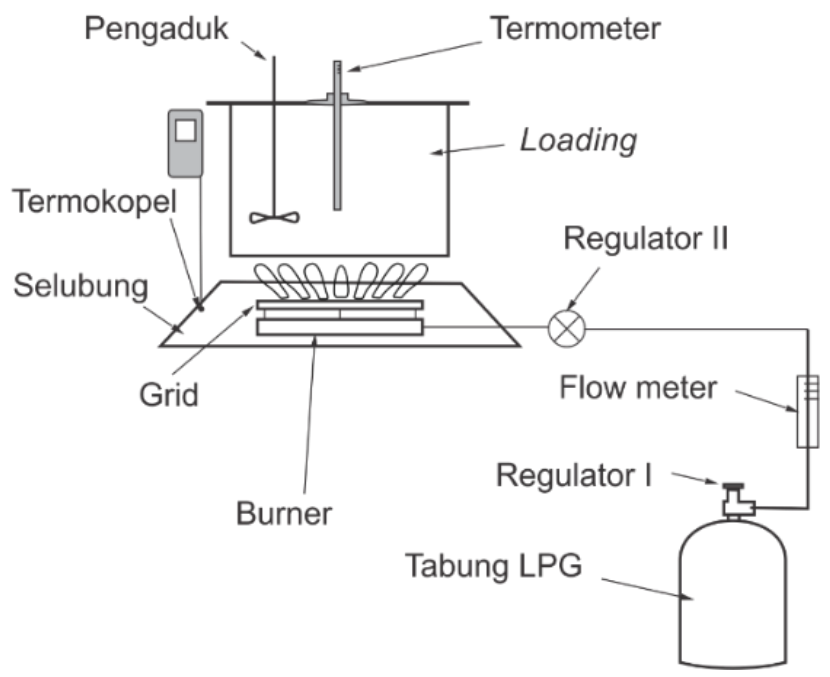

Gambar 1. Instalasi penelitian

Temperatur air diukur dengan menggunakan termometer alkohol tipe AL-30100-010 dengan range pengukuran $-10^{\circ} \mathrm{C}-110^{\circ} \mathrm{C}$. Loading dilengkapi dengan sebuah pengaduk agar temperatur air merata mewakili temperatur air yang dibaca oleh termometer. Untuk mengetahu energi yang hilang akibat adanya radiasi, permukaan selubung kompor diukur dengan menggunakan termokopel probe tipe $\mathrm{K}$ yang dipasang pada thermometer set merk KRISBOW KW06-278 Single Input Digital Thermometer. Sedangkan untuk mengontrol laju aliran massa bahan bakar dipergunakan dua buah regulator yang masingmasing ditempatkan diantara flow meter dan burner serta diantara tabung LPG dan flow meter.

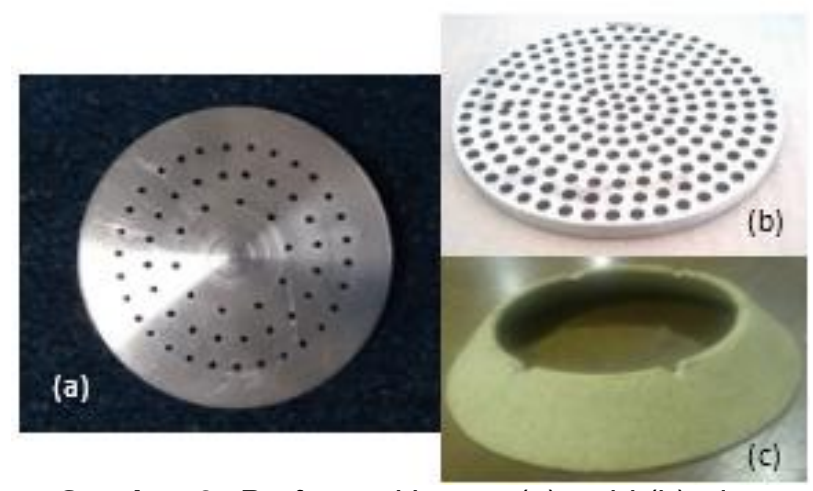

Gambar 2. Perforated burner (a); grid (b); dan selubung kompor (c) yang digunakan dalam penelitian
Konsep efisiensi pada penelitian ini adalah nilai energi yang diserap oleh air di dalam loading (massa loading tidak di hitung) dibagi dengan nilai energi yang hasilkan oleh bahan bakar LPG seperti terlihat pada Persamaan (1).

$$
\eta=\frac{m_{w} C_{w} \Delta T}{m_{f} L H V_{f}} \times 100 \%
$$

dimana $m_{w}$ adalah massa air, $C_{w}$ adalah panas jenis air dan $\Delta T$ adalah perbedaan awal dan temperatur akhir air, $m_{f}$ adalah massa bahan bakar, $L H V_{f}$ adalah nilai kalor bahan bakar.

Energi selain energi yang diserap air diasumsikan sebagai energi yang hilang. Asumsi tersebut di ambil karena proses pengukuran energi yang hilang akibat proses perpindahan konduksi, konveksi dan radiasi relatif sulit untuk di identifikasi akibat bentuk geometri instalasi sistem pemanasan. Parameter yang relatif mudah untuk diukur adalah energi radiasi dari selubung dengan menggunakan Persamaan (2).

$$
\dot{Q}_{\text {rad,sel }}=e \sigma A T^{4}
$$

dimana $A$ = luas penampang, $e$ adalah bahan dan $\sigma$ adalah konstanta Boltzmann yang bernilai $5.67 \times 108$ $\mathrm{W} / \mathrm{m}^{2}$. $\mathrm{K}^{4}$

Perhitungan energi yang hilang dilakukan dengan menggunakan Persamaan (3), dimana energi hilang merupakan energi selain energi yang diserap oleh air dan energi radiasi yang dipancarkan oleh selubung kompor.

$$
E_{b b}=E_{w}+E_{\text {rad.sel }}+E_{l}
$$

dimana $E_{b b}$ adalah energi yang dihasilkan melalui proses pembakaran, $E_{w}$ adalah energi yang diserap oleh air, $E_{r a d, s e l}$ adalah energi yang dipancarkan oleh selubung dan $E_{l}$ adalah energi yang hilang.

Prosedur perhitungan efisiensi dari sistem pemanasan ini dilakukan dengan pendefinisian input dan output energi seperti pada persamaan (1). Efisiensi dihitung persatuan waktu sampai seluruh air mendidih.

\section{Kondisi Penelitian}

Kondisi penelitian, nilai kalor bahan bakar LPG serta spesikfikasi bahan penelitian lainnya dapat dilihat pada Tabel 1. Temperatur atmosfer ruangan pada saat dilakukan penelitian di asumsikan sebesar $25^{\circ} \mathrm{C}$ dan temperatur akhir sebagai kondisi mendidih adalah $95^{\circ} \mathrm{C}$ akibat dari topografi lokasi penelitian yang berada di ketinggian $\pm 476 \mathrm{~m}$ dari permukaan laut. Kondisi mendidih pada penelitian ini didefisinikan ketika air di dalam loading mulai terjadi gelembunggelembung pada sekitar $50 \%$ permukaan. Panas jenis air yang digunakan adalah panas jenis air rata-rata pada temperatur operasi. Nilai LHV bahan bakar yang digunakan juga merupakan proporsional komposisi dari bahan bakar LPG sebesar $46,4 \mathrm{MJ} / \mathrm{kg}$. 
Tabel 1. Kondisi penelitian

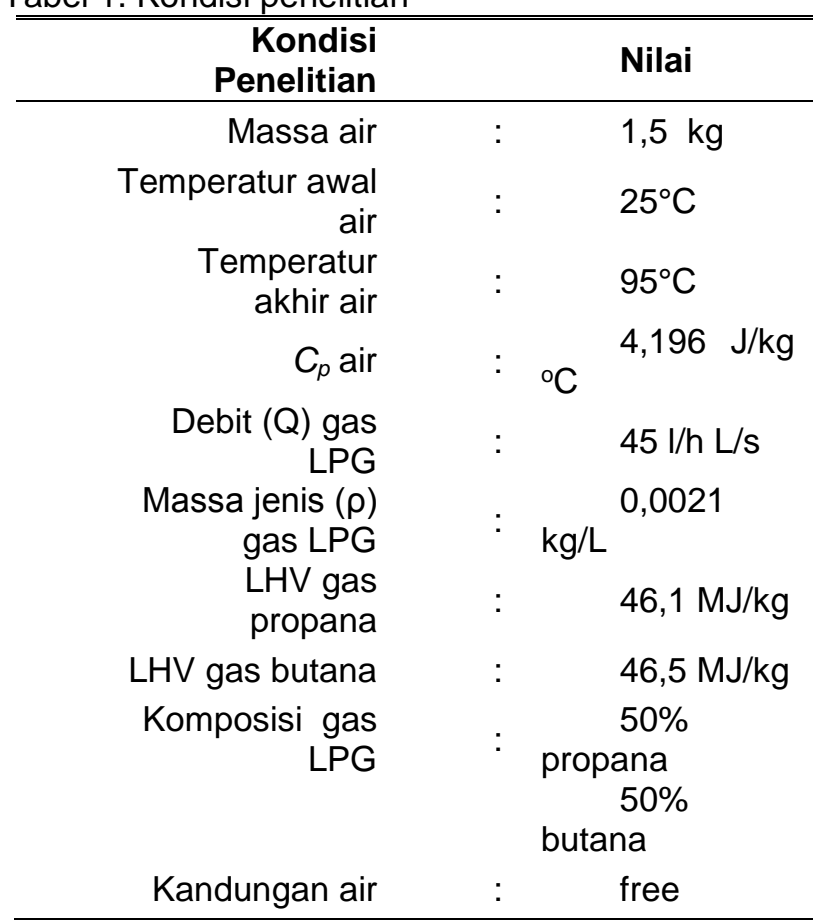

\section{HASIL DAN PEMBAHASAN}

Gambar 3 adalah grafik efisiensi per satuan waktu sistem pemanasan dengan grid dan tanpa grid. Seperti terindikasi pada gambar 3. bahwa efisiensi sistem pemanasan pada awal pemanasan lebih rendah dibandingkan dengan sistem pemanasan dengan penambahan grid. Penurunan efisiensi pada awal pemanasan tersebut disebabkan panas yang dihasilkan oleh proses pembakaran terserap oleh material grid. Tetapi sampai batas waktu sekitar 238,5 detik (vertical dash line), efisiensi sistem pemanasan mulai meningkat melebihi efisiensi sistem pemanasan tanpa grid.

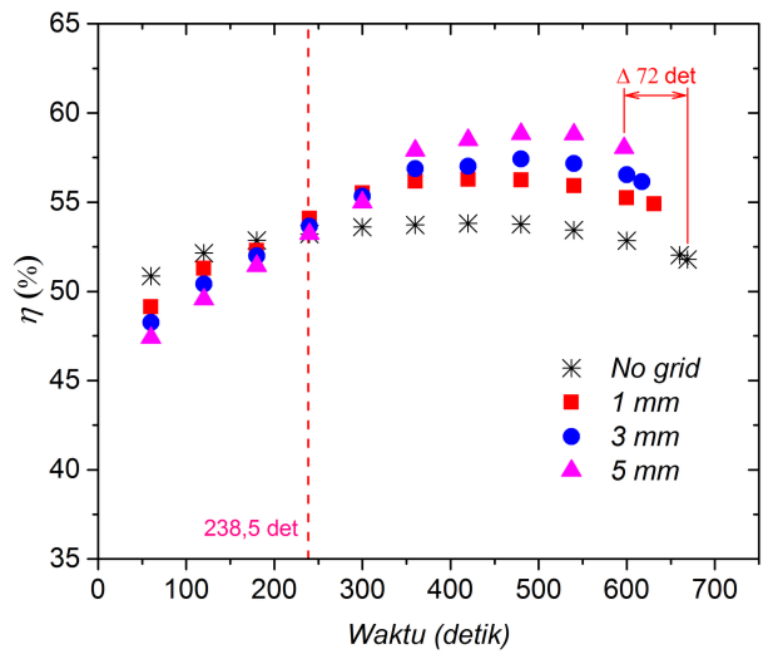

Gambar 3. Efisiensi kompor per satuan waktu untuk system pemansan dengan menggunakan grid dan tanpa grid

Efisiensi sistem pemanasan juga cenderung meningkat dengan semakin tebal. Sistem pemanasan dengan tebal grid $5 \mathrm{~mm}$ mempunyai efisiensi maksimal terbesar dibandingkan grid dengan tebal 1 dan $3 \mathrm{~mm}$. Dengan semakin tebal grid panas yang di serap oleh material grid akan tersimpan pada grid menyebabkan temperatur di ruang bakar akan semakin tinggi. Semakin tinggi temperatur ruang bakar akan memicu proses pembakaran semakin lebih baik, karena panas sensibel bahan bakar akan meningkat mendekati titik nyala bahan bakar. Hal ini sesuai dengan teori Arrhenius bahwa kecepatan reaksi kimia suatu proses pembakaran sangat dipengaruhi oleh temperatur. Semakin tinggi temperatur, semakin tinggi pula kecepatan reaksi proses pembakaran. Dari persamaan Arrhenius, peningkatan temperatur sebesar $10^{\circ} \mathrm{C}$ akan meningkatkan kecepatan reaksi hampir dua kali lipat dibandingkan dengan sebelumnya.

Efisiensi maksimal terjadi pada sistem pemanasan dengan tebal grid $5 \mathrm{~mm}$ dengan nilai sebesar $58,8 \%$. Terjadi peningkatan efisiensi sebesar $5 \%$ jika dibandingkan dengan sistem pemanasan tanpa grid. Selisih waktu pemanasan dengan menggunakan grid tebal $5 \mathrm{~mm}$ dengan tanpa grid adalah sebesar 72 detik atau sebanding dengan energi sebesar $87,6 \mathrm{~kJ}$.

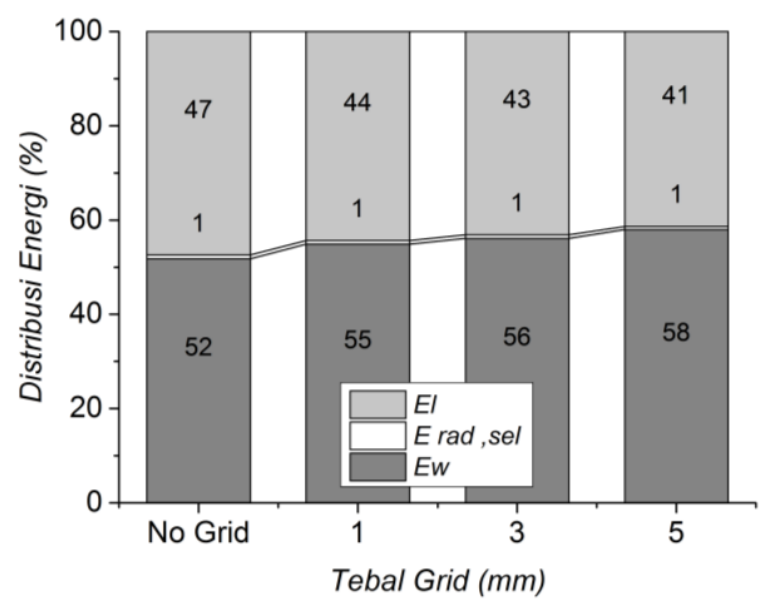

Gambar 4. Distribusi energi pada sistem pemanasan dengan dan tanpa grid

Gambar 4. menunjukan distribusi energi yang terjadi pada sebuah sistem pemanasan dengan dan tanpa grid. Terlihat pada gambar bahwa dengan penambahan grid pada sebuah sistem pemanasan dapat meningkatkan jumlah energi yang diserap oleh air dan sebaliknya menurunkan jumlah energi yang hilang. Energi radiasi oleh selubung tercatat $<1 \%$ dari seluruh yang dihasilkan bahan bakar, akan tetapi pemakaian selubung keramik saja dapat meningkatkan efisiensi sebuah sistem pemanasan sebesar 2,6\% dibandingkan dengan tanpa selubung [12].

Penambahan grid diantara burner dan loading akan memicu terjadinya turbulensi aliran di atas grid seperti terlihat pada gambar 5 . Turbulensi yang dibangkitkan oleh grid akan memperbaiki proses 
pencampuran bahan bakar dan udara dibandingkan dengan sistem pemanasan tanpa grid. Gambar 5 (a) memperlihatkan sebuah sistem pemanasan tanpa menggunakan grid, diikuti dengan sistem pemanasan dengan penambahan grid dengan tebal $1 \mathrm{~mm}, 3 \mathrm{~mm}$, dan $5 \mathrm{~mm}$ pada Gambar 5 (b), (c) dan (d) berturutturut. Terlihat pada Gambar 4 bahwa bentuk api berubah ketika ada penambahan grid diantara burner dan loading. Api semakin tebal dibagian bawah diatas permukaan grid (Gambar 5 (c)). Terlihat pula bahwa turbulensi semakin intensif pada pangkal api ketika grid ditambahkan dan juga dengan bertambahnya ketebalan dari grid. Grid yang semakin tebal akan meningkatkan temperatur rata-rata di ruang bakar dan temperatur diatas grid menjadi lebih tinggi membuat intensitas pembakaran di atas grid juga semakin intensif.

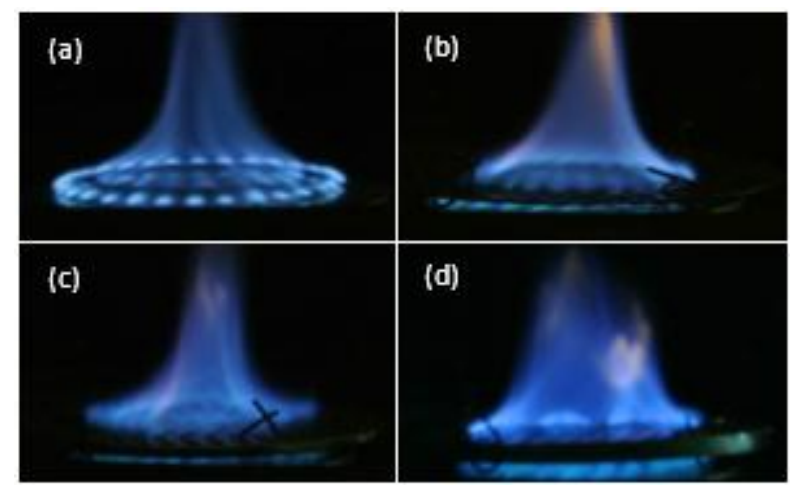

Gambar 5. Karakteristik api pada burner perforated tanpa loading dengan kondisi tanpa grid (a); dengan grid $1 \mathrm{~mm}$ (b); grid $3 \mathrm{~mm}$ (c); dan grid $5 \mathrm{~mm}$ (d)

\section{KESIMPULAN DAN SARAN}

Pada penelitian ini sebuah investigasi untuk mengukur performansi sebuah sistem pemanasan dengan penambahan sebuah grid diantara burner dan loading telah dilakukan. Hasil penelitian dibandingkan pula dengan sebuah sistem pemanasan tanpa penambahan grid. Dari diskusi dan pembahasan dapat diambil kesimpulan sebagai berikut.

Pada sebuah massa alir konstan sebesar $0.45 \mathrm{l} / \mathrm{h}$ nbahan bakar LPG, efisiensi sebuah sistem pemanasan diperoleh pada grid dengan tebal $5 \mathrm{~mm}$. Efisiensi tertinggi yang diperoleh adalah $58.8 \%$ lebih besar dibandingkan dengan penggunaan grid dengan tebal $1 \mathrm{~mm}$ dan $3 \mathrm{~mm}$, apalagi jika dibandingkan dengan sistem pemanasan tanpa grid. Penambahan grid pada sebuah sistem pemanasan diantara burner dan loading dapat menyimpan panas, merubah karakteristik api sehingga dapat meningkatkan efisiensinya.

\section{UCAPAN TERIMA KASIH}

Penulis mengucapkan banyak terima kasih kepada Fakultas Teknik Universitas Brawijaya atas biaya DIPA yang diberikan dengan nomor kontrak No.17/UN.10.6/PG/2015 sehingga penelitian ini dapat terselesaikan. Ucapkan terima kasih pula penulis sampaikan kepada saudara Ade Cahyo Utomo atas bantuan dalam pelaksanaan penelitian ini serta semua pihak yang tidak dapat penulis sebutkan satu persatu.

\section{DAFTAR PUSTAKA}

[1] Muthukumar P., Shyamkumar P. 2013. Development of novel porous radiant burners for LPG cooking applications. Fuel;112 : 562-566.

[2] Konversi BBM ke Gas, Kurangi Subsidi BBM Jangka

Panjang, http://www.esdm.go.id/berita/40-migas/5515konversi-bbm-ke-gas-kurangi-subsidi-bbmjangka-panjang.html.

[3] Konversi Mitan Ke LPG Hemat Rp 70 Triliun", 2014. http://www.esdm.go.id/berita/migas/40migas/ 6513-konversi-mitan-ke-lpg-hemat-rp-70triliun.html).

[4] Ko YC, Lin T-H. 2003. Emissions and Efficiency Of a Domestic Gas Stove Burning Natural Gases With Various Compositions. Energi Conversion and Management;44:3001-3014.

[5] Hou S-S, Ko Y-C. 2005. Influence of Oblique Angle And Heating Height on Flame Structure, Temperatur Field And Efficiency of An Impinging Laminar Jet Flame. Energi Conversion and Management;46:941-58.

[6] Dongbin. Z., Jinsheng, L., Guangchuan, L.,Yan, D., Gang. X. and Lihua L., 2007 "Effects on Combustion of Liquefied Petroleum Gas of Porous Ceramic Doped With Rare Earth Elements", J. Rare Earths; 25:212-25.

[7] Kandpal B, Maheswari RC, Kandpal TC. 1995. Indoor Air Pollution From Domestic Cooking Stoves Using Coal Kerosene and LPG. Energi Conversion and Management;36:106

[8] Pantangi VK, Karuna Kumar ASSR, Mishra SC, Sahoo N. 2007. Performance Analysis of Domestic LPG Cooking Stoves With Porous Media. RERIC International Energi Journal;8:139e44.

[9] Trimis D, Durst F. 1996. Combustion In a Porous Medium-Advances and Applications. Combustion Science and Technology;121:153.

[10] Mujeebu M.A, Abdullah M.Z, Abu Bakar M.Z, Mohamad A.A, Abdullah M.K. 2009. Applications of Porous Media Combustion, technology e a review. Applied Energi.

[11] Mishra N.K, Muthukumar P., Mishra S.C. 2013. Performance Tests on Medium-Scale Porous Radiant Burners for LPG Cooking Applications, International Journal of Emerging Technology and Advanced Engineering, Volume 3, Special Issue 3: ICERTSD, Feb 2013, pages 126-130, ISSN 2250-2459.

[12] Widodo A.S. 2015. Jarak Optimum Panci Terhadap Selubung Pada Efisiensi Sistem Pemanasan Air, Jurnal Rekayasa Mesin Vol.6, No.1, Hal:69-73.

[13] Gohil , P.P and Channiwala, S.A., 2011., "Fundamental J. Thermal Science and Engineering", Vol. 1, Issue 1, 2011, Pages 25-34 
[14] Widodo A.S 2014. Selubung Radiasi Untuk Efisiensi Penggunaan Energi Pada Kompor Gas, Jurnal Rekayasa Mesin Vol. 5. No. 3

[15] Syarial, M., 2012, "Unjuk Kerja Kompor Berbahan Bakar Biogas Efisiensi Tinggi Dengan Penambahan Reflektor"., Skripsi Unpublihed 2012. Institut Teknologi Sepuluh November. Surabaya.
[16] Wardani, D. 2007. "Alat Penghemat Bahan Bakar Gas Pada Kompor Gas Rumah Tangga". Skripsi Unpublished. Institut Teknologi Bandung.

[17] Khan, M.Y and Saxena A. 2013." Performance of LPG Cooking Stove Using Different Design Of Burner Heads", International Journal of Engineering Research \& Technology (IJERT), ISSN: 2278-0181, Vol. 2 Issue 7. 